
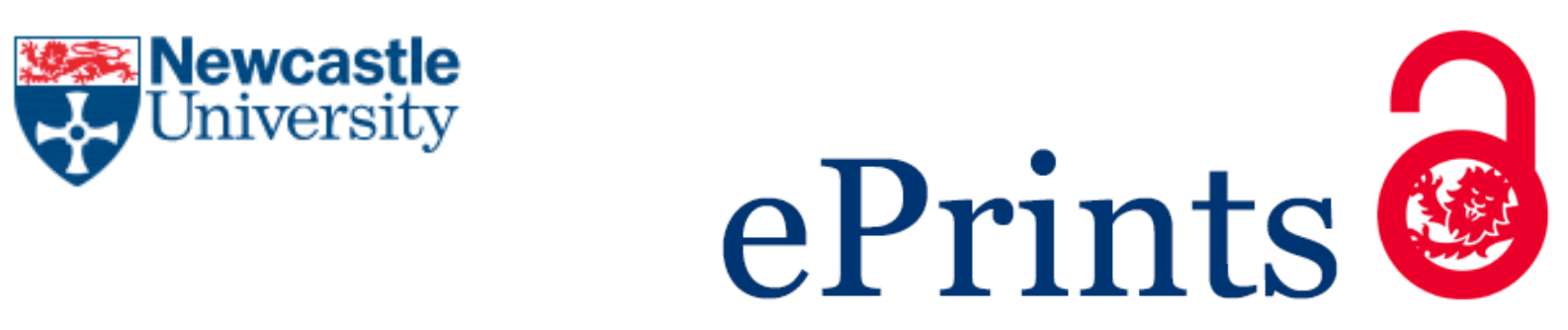

Tang ZS.

Consumer contracts and the Internet in EU private international law.

In: Savin, A; Trzaskowski, J, ed. Research Handbook on EU Internet Law.

Cheltenham: Edward Elgar, 2014, pp.254-284.

\title{
Copyright:
}

This is a draft chapter / article. The final version is available in Research Handbook on EU Internet Law edited by Savin, A; Trzaskowski, J, published in 2014 by Edward Elgar Publishing Ltd. The material cannot be used for any other purpose without further permission of the publisher, and is for private use only.

URL link to book:

http://www.e-elgar.com/shop/research-handbook-on-eu-internet-law

Date deposited:

$02 / 05 / 2017$

Embargo release date:

26 March 2015 


\section{Consumer contracts and the Internet in EU private international law}

\section{Zheng Sophia Tang}

\section{INTRODUCTION}

The Internet has great potential when it is used in the commercial field. It is an effective low-cost instrument that could enable small and medium sized businesses to access foreign markets without extra cost. It also empowers consumers who can select from many suppliers and compare the quality, services, and prices to make the best choice. ${ }^{1}$ The Internet has the potential to build a truly global borderless market. In the EU, the internal market could benefit from the Internet which could remove internal frontiers, eliminate physical and cost barriers and facilitate free movement of goods, free movement of services, and freedom of establishment. ${ }^{2}$ On the other hand, the opportunities are associated with commercial risk. Where disputes have arisen, the parties would wonder which country they might sue or be sued in and which country's substantive law should apply to decide their rights and obligations. Without clear and well-designed jurisdiction and choice of law rules, uncertainty would hamper the development of consumer-oriented e-commerce.

Proper private international law, which is compatible with the special characteristics of the Internet and appropriate to balance the conflict of interest between consumers and e-businesses, thus becomes necessary and important. Traditionally, private international law functions to allocate a particular contractual relationship within the territory of a country based either on the party's intention or on the objective connecting factors. ${ }^{3}$ Although the Internet has brought challenges to the traditional connecting factors in contracts, ${ }^{4}$ it does not lead to the necessity for any fundamental reform except the need for special construction and interpretation in the context of the Internet. ${ }^{5}$ The doctrine of party autonomy basically could stand intact from the challenge of the Internet. ${ }^{6}$ Electronic commerce may only challenge the formal requirements of a choice of court or choice of law agreement, but once this

\footnotetext{
${ }^{1}$ Many e-compare websites are established to provide the best choice for the consumers. For example, the travel and hotel comparison website, www.travelsupermarket.com; the website comparing electronic products, www.kelkoo.co.uk; the product comparison site, www.pricerunner.co.uk.

${ }^{2}$ Directive 2000/31/EC on certain legal aspects of information society services, in particular electronic commerce, in the Internal Market, [2000] OJ L178/1, Recital 1.

${ }^{3}$ See in general, Fawcett J. and J.M. Carruthers (2008), Cheshire, North and Fawcett: Private International Law, 14th edn., Oxford: Oxford University Press, pp. 20-37; Hartley, T.C. (2009), International Commercial Litigation, Cambridge: Cambridge University Press, pp. 15-16, 566-97; Von Mehren A.T. (2002), 'Theory and practice of adjudicatory authority in private international law', in Collected Courses, Vol. 295, The Hague, Boston and London: Martinus Nijhoff Publishers; Blom, J. $(1978,1979,1980)$ 'Choice of Law Methods in the Private International Law of Contract' 16 Canadian Yearbook of International Law 230; 17 Canadian Yearbook of International Law 206; 18 Canadian Yearbook of International Law 161; Clarkson, C.M.V. and J. Hill (2011), The Conflict of Laws, 4th edn., Oxford: Oxford University Press, pp. 7-9, 33.

${ }^{4}$ Such as the interpretation of the place where an e-contract is concluded, the place of delivery of a digital product online, and the place where online services are provided.

${ }^{5}$ Fawcett J.J., Harris, J. and M. Bridge (2005), International Sale of Goods, Oxford: Oxford University Press, paras 10.242-10.258; Hill, J. (2008), Cross-Border Consumer Contracts, Oxford: Oxford University Press, pp. 149-50; Z.S. Tang (2009), Electronic Consumer Contracts in the Conflict of Laws, Oxford: Hart Publishing, pp. 17-18.

${ }^{6}$ Tang, supra n. 5, p. 18.
} 
agreement is proved to be validly concluded, jurisdiction and applicable law are easy to determine. ${ }^{7}$ Unfortunately, both doctrines have limited application in consumer contracts. In the EU, the legislators want to protect consumers as the weaker party in international transactions and provide protective jurisdiction and choice of law rules in consumer contracts. ${ }^{8}$ The protective conflict rules depart from the traditional technical culture of private international law and introduce consideration to protecting rights of consumers. ${ }^{9}$ The Internet challenges the proper functioning of EU private international law in cross-border consumer contracts. The private international law challenge increases commercial risk and uncertainty and reduces the confidence of both consumers and businesses in e-commerce. In order to promote e-commerce, legislators have worked to reform traditional private international law to provide certainty and predictability and to reduce unnecessary legal barriers to consumer contracts on the Internet. ${ }^{10}$ The European legislators responded to the request to reconsider consumer conflict of laws in e-commerce during the late 1990s when the Brussels Convention was converted into the Brussels I Regulation. ${ }^{11}$ A similar reform was adopted again when the Rome Convention was converted into the Rome I Regulation by the end of 2000s. ${ }^{12}$ Section II briefly introduces the historic development of European consumer private international law and the reform by taking account of the Internet's influence.

Not all consumers will be protected in conflict of laws. The protective rules will only apply to certain consumer contracts. Section III generally explains the scope of protection taking aboard the special characteristics and special consumer contracts in e-commerce. The protective conflicts rules are generally based on the principle of 'targeting', that is, if the e-business, by adopting the Internet in its marketing and selling strategy, targets the consumer's domicile or habitual residence, the e-business should be subject to the jurisdiction and domestic law of the consumer's home, ${ }^{13}$ and

\footnotetext{
${ }^{7}$ As to the formal validity in e-commerce, see UK Law Commission, 'Electronic Commerce: Formal Requirements in Commercial Transactions', Dec 2001; Tang, supra n. 5, pp. 123-30. It is common understanding now that agreements concluded through electronic means should not be denied their validity. See Regulation 44/2001 on Jurisdiction and the Recognition and Enforcement of Judgments in Civil and Commercial Matters (Brussels I Regulation), art. 23(2); UNCITRAL Model Law on Electronic Commerce 1996, art. 8(1) and 8(3)(a).

${ }^{8}$ Arts 15-17, Brussels I Regulation; art. 6, Regulation 593/2008 on the Law Applicable to Contractual Obligations (Rome I Regulation). The same targeting test was adopted in the old version, Arts 13-15, Convention on jurisdiction and the enforcement of judgments in civil and commercial matters (Brussels Convention) and art. 5, Convention on the Law Applicable to Contractual Obligations (Rome Convention).

${ }^{9}$ Gillies, L. (2003), 'Adapting international private law rules for electronic consumer contracts' in Richett, C. and T. Telfer (ed.), International Perspectives on Consumers' Access to Justice, Cambridge University Press, p. 359; Hartley, T. (1982), 'Consumer Protection Provisions in the EEC Convention' in North, P. (ed), Contract Conflicts, Amsterdam: North-Holland Publishing, p. 111; Tang, supra n. 5, pp. 4-8.

${ }^{10}$ Tang, supra n. 5, 7.

11 European Council, 'Council Working Party on the Revision of the Brussels and Lugano Conventions', JUSTCIV 60. For more details, see Beaumont, P. (2002), 'The Brussels Convention becomes a regulation' in Fawcett, J. (2002), Reform and Development of Private International Law, Oxford: Oxford University Press, p. 9; Kennett, W. (2001), 'The Brussels I Regulation', ICLQ 725; J. Harris, J. (2001), 'The Brussels Regulation', Civil Justice Quarterly 218; Crawford, E.B. and J.M. Carruthers (2006), International Private Law: A Scots Perspective, 2nd edn., Edinburgh: W. Green, pp. 429-32.

${ }^{12}$ European Commission, 'Green Paper on the Conversion of the Rome Convention of 1980 on the Law Applicable to Contractual Obligations into a Community Instrument and its Modernisation' $\operatorname{COM}(2002) 654$ final.

${ }^{13}$ Art. 15,Brussels I Regulation; art. 6(1) Rome I Regulation.
} 
the application of the traditional private international law doctrine of party autonomy is limited. ${ }^{14}$ The concept of 'targeting', however, is particularly troublesome on the Internet. It is widely known that the Internet is a powerful instrument that has almost unlimited and international reach. Once a website is established, it is accessible almost everywhere in the world. ${ }^{15} \mathrm{~A}$ broad interpretation of 'targeting' based purely on accessibility would bring high risks to e-businesses. Although modern technology provides the possibility of limiting the reach and accessibility of a website and some contents, the extra expense of such technology would increase cost and may discourage small and medium-sized companies from engaging in e-commerce. A narrow interpretation of 'targeting', on the other hand, may be unfair to consumers, who may be required to bring an action in a foreign country or may have to construe their rights and obligations under the law of another country - something not necessarily expected or even noticed by the consumer, as a layman, before completing the transaction. The European legislators have faced a difficult task in balancing the conflicting interest between consumers and e-businesses, especially small and medium sized companies. ${ }^{16}$ The interpretation of 'targeting' is discussed in Section IV.

While some commentators continue to criticize European protective conflict of laws in e-consumer contracts and try to provide alternatives to suit the development of consumer-oriented e-commerce, other commentators realize that the protective conflict of laws is used very infrequently in practice. They consider it a matter of fact that most e-consumer contracts are of small value which makes litigation, either in consumers' home state or in a foreign country, unreasonable. As a result, the worry about the negative effects of protective private international law in the e-commerce practice is not realistic. ${ }^{17}$ Consumers' better access to justice on the Internet should be provided by alternative dispute resolution (ADR) methods, or by collective redress. This view is shared by the European legislators. The European Commission has considered issues much broader than purely private international law in cross-border individual litigation, including out-of-court dispute resolution and collective redress. The ECC-Net, a Europe-wide network of the 29 European Consumer Centres in all EU countries, Norway and Iceland, for example, helps consumers and businesses to resolve cross-border disputes. ${ }^{18}$ The EU also adopted a consumer ADR Directive ${ }^{19}$ and a consumer Online Dispute Resolution (ODR) Regulation in June 2013. ${ }^{20}$ In 2013 , the European Commission published the recommendation on common principles for

\footnotetext{
${ }^{14}$ Art. 17, Brussels I Regulation; art. 6(2), Rome I Regulation.

${ }^{15}$ Svantesson, D.J.B. (2007), Private International Law and the Internet, The Hague/London/Boston: Kluwer Law International, ch 2; Puurunen, T. (2002), 'The judicial jurisdiction of States over international business-to-consumer electronic commerce from the perspective of legal certainty' $8 U C$ Davis Journal of International Law and Policy 133; Burnstein, M. (2001), 'A global network in a compartmentalised legal environment', in Boele-Woelki, K. and C. Kessedjian (eds), Internet: Which Court Decides? Which Law Applies?, The Hague/London/Boston: Kluwer Law International, p. 32.

${ }^{16}$ Economic and Social Committee, 'Opinion of the Economic and Social Committee on the 'Proposal for a Council Regulation (EC) on jurisdiction and the recognition and enforcement of judgments in civil and commercial matters' [2000] OJ C117/6, para. 4.2.2.

${ }^{17}$ Hill, supra n.5, p. 2.

${ }^{18}$ For more on the ECC-Net, see http://ec.europa.eu/consumers/ecc/index_en.htm, accessed 15 April 2014.

${ }^{19}$ Directive 2013/11/EU on Alternative Dispute Resolution for Consumer Disputes and Amending Regulation (EC) No 2006/2004 and Directive 2009/22/EC, [2013] OJ L165/63.

${ }^{20}$ Regulation (EU) No 524/2013 on Online Dispute Resolution for Consumer Disputes and Amending Regulation (EC) No 2006/2004 and Directive 2009/22/EC (Regulation on consumer ODR), [2003] OJ L165/1.
} 
collective redress mechanisms in the Member States. ${ }^{21}$ It is believed that the combination of different dispute resolution methods would effectively improve consumers' access to justice in the cross-border context. Section V finally considers the development of the multiple dispute resolution scheme in Europe and the application of private international law in ADR/ODR and collective action. Section VI concludes that the European consumer private international law is generally appropriate in cross-border individual consumer litigation and it does not cause barriers to the development of e-commerce. It, however, needs to be developed further in order to cope with other dispute resolution methods, which may prove more effective in resolving consumers' cross-border access to justice.

\section{EUROPEAN PRIVATE INTERNATIONAL LAW IN CONSUMER CONTRACTS}

One special characteristic of EU private international law is that the EU has taken a pioneering role in introducing protective jurisdiction and choice of law rules to consumer contracts, with the special purpose of protecting consumers versus businesses. The protective private international law was first introduced in the area of jurisdiction in the Brussels Convention of $1968,{ }^{22}$ which only covers instalment sales and loans. ${ }^{23}$ The protection was later extended to more consumer contracts ${ }^{24}$ and was equally adopted in the choice of law rules in the Rome Convention of $1980 .{ }^{25}$ The Brussels Convention provides that consumers are entitled to sue and be sued in their domicile $^{26}$ as far as the contract was preceded by a specific invitation or by advertising and the consumer took all the necessary steps to conclude the contract in that state. ${ }^{27}$ The choice of court agreement in such contracts will only be enforceable if it is entered into after the dispute has arisen, provides consumers with additional forum/fora to bring the action, or designates the common domicile of both parties at the time of contracting. ${ }^{28}$ The Rome Convention provides that in contracts satisfying the same conditions, ${ }^{29}$ the parties' choice of law cannot deprive consumers of the protection of the mandatory rules of the law of the consumer's habitual residence. ${ }^{30} \mathrm{In}$ the absence of choice, the law of the consumer's habitual residence shall apply as the default applicable law. ${ }^{31}$

Both provisions were established long before the Internet was widely adopted in business activities. There is no doubt that the traditional provision has not taken into consideration distance-selling methods, especially the use of Internet in pursuing

\footnotetext{
${ }^{21}$ European Commission, 'Commission Recommendation on Common Principles for Injunctive and Compensatory Collective Redress Mechanisms in the Member States Concerning Violations of Rights Granted under Union Law', C(2013) 3539/3.

${ }^{22}$ Convention of 1968 on Jurisdiction and the Enforcement of Judgments in Civil and Commercial Matters (Brussels Convention), [1972] OJ L299/32, arts 13-15.

${ }^{23}$ P. Jenard, P. (1979), 'Report on the Convention on Jurisdiction and the Enforcement of Judgments in Civil and Commercial Matters' ('Jenard Report') [1979] OJ C59/1, 33.

${ }^{24}$ The Convention on the Accession of the Kingdom of Denmark, Ireland and the United Kingdom of Great Britain and Northern Ireland to the Convention on Jurisdiction and the Enforcement of Judgments in Civil and Commercial Matters, [1978] OJ L304/77, arts 13-15.

${ }^{25}$ Convention on the law applicable to contractual obligations, [1980] OJ L 266/1, art. 5(1).

${ }^{26}$ Art 14.

${ }^{27}$ Art. 13(3).

${ }^{28}$ Art. 15.

${ }^{29}$ Art. 5.

${ }^{30}$ Art. 5(2).

${ }^{31}$ Art. 5(3).
} 
commercial activities. After the Internet was developed in the 1990s, commentators started to criticize the likely negative effect of the existing private international rules. $^{32}$ The most common criticism lies in two areas: first, this provision excludes 'mobile' consumers from being protected even though the business purposely targets the consumer's domicile and could reasonably expect to be subject to the jurisdiction of that country; ${ }^{33}$ second, it requires a 'special invitation' or 'advertising' to be made in the consumer's domicile, and it is hard to construe whether such requirements are met on the Internet, where the traditional methods of invitation and advertising are no longer in use. ${ }^{34}$

The protective jurisdiction was subject to reform during the process of converting the Brussels Convention into the Brussels I Regulation. The European Commission has proposed to change the condition into a more flexible and Internetcompatible one. The new arrangement states that the protective conflicts rules are applicable if:

'the contract has been concluded with a person who pursues commercial or professional activities in the Member State of the consumer's domicile or, by any means, directs such activities to that Member State or to several States including that Member State, and the contract falls within the scope of such activities. ${ }^{35}$

This change was adopted in the final version of the Brussels I Regulation. This provision has caused concerns mainly from e-businesses who worry that the globalizing nature of the Internet may subject e-businesses to potential actions in every Member State unless sufficient methods are employed to ring-fence the market. ${ }^{36}$ Questions and concerns continue to arise in terms of the appropriate interpretation of the term 'pursue in' and 'direct to' on the Internet. Although it has been repeatedly confirmed by the European Commission as well as commentators that the simple 'accessibility' of a website in a Member State is insufficient to trigger the protective conflict of laws, without official clarification and uniform interpretation of these terms, uncertainty continues to exist amongst e-commerce participants which continues to hamper potential active e-commerce players from being fully engaged in commercial activities. This issue will be discussed in detail in Section IV below.

Regardless of all the questions, when the Rome Convention became the Rome I Regulation, the same reform was adopted. It is also noted that the Brussels I Regulation has undergone a reform and will be replaced by the Brussels I Recast from 10 January $2015 .{ }^{37}$ The protective jurisdiction rules on consumer contracts were not, in that instrument, subject to reform, which shows that, irrespective of academic

\footnotetext{
${ }^{32}$ See van der Hof, S. (2003), 'European conflict rules concerning international online consumer contracts' 12 Information \& Communication Technology Law 165; Foss M and L Bygrave (2000), 'International consumer purchases through the internet: Jurisdictional issues pursuant to European law' 8 International Journal of Law and Information Technology 99; Puurunen, T. (2002), 'The judicial jurisdiction of states over international business-to-consumer electronic commerce from the perspective of legal certainty' 8 UC Davis Journal of International Law and Policy 133; Riefa, C. (2004) 'Article 5 of the Rome Convention on the law applicable to contractual obligations of 19 june 1980 and consumer e-contracts: The need for reform' 13(1) Information and Communications Technology Law 59.

${ }^{33}$ Economic and Social Committee Opinion, para 4.2.4.

${ }^{34}$ Foss and Bygrave, supra n. 32, 124; Debussere, F. (2002), 'International jurisdiction over econsumer contracts' 10 International Journal of Law and Information Technology 344, 355.

${ }^{35}$ Art. 15(1)(c) Brussels I Regulation; art. 6(1) Rome I Regulation.

${ }^{36}$ European Commission, 'Proposal for a Council Regulation (EC) on Jurisdiction and the Recognition and Enforcement of Judgments in Civil and Commercial Matters, [1999] OJ C 376E/1, art 15.

${ }^{37}$ Regulation (EU) No 1215/2012 on Jurisdiction and the Recognition and Enforcement of Judgments in Civil and Commercial Matters (Recast), [2012] OJEU L351/1.
} 
concerns, the legal reality does not demonstrate as great a difficulty and challenge as has been presumed. The legislator, as a result, does not see the necessity to further reform the current protective conflict of laws in consumer contracts.

\section{SCOPE OF PROTECTION}

European private international law provides pioneering rules for consumer protection, but it does not protect consumers per se. There is a strict limitation as to who should be protected. The scope of protection depends on: (1) the identity of the parties; (2) the type of contracts; (3) in terms of jurisdiction, the defendant being domiciled or deemed to be domiciled in the EU; (4) the expectation of the parties.

\section{A. Identity of the Parties}

Needless to say, the protection applies to a contract where one party must be a 'consumer'. A consumer is defined as a natural person who has concluded a contract for the purpose 'outside his trade or profession'. ${ }^{38}$ The line between consumers and non-consumers, however, is ambiguous. In the existing ten CJEU decisions concerning the application of art. 15 of the Brussels I Regulation (art. 13 of the Brussels Convention), four relate to whether the claimant is qualified as a 'consumer'. ${ }^{39}$ This is mainly because the concept 'purpose outside trade or profession' is unclear. Some professions are unconventional. For example, some individuals are part-time investors, who purchase to acquire profits instead of consumption. ${ }^{40}$ It is also uncertain whether the protective rules should only apply if the other party, the business, could reasonably expect that it is trading with a consumer. It is particularly hard for a business to predict the purpose of a purchase in online trading due to the fact that most such trading involves low-value transactions that may attract both consumers and business buyers. The application of protective conflict of laws does not depend on whether the identity of the buyer should be disclosed and appreciated by the seller at the time of contracting. Inasmuch as the buyer is a consumer, the protective rules shall apply. This has imposed uncertainty on online traders.

\section{B. Type of Contracts}

Not all contracts fall within the scope of consumer protection. Neither the protective jurisdiction nor choice of law rules apply to transport contracts. ${ }^{41}$ This is mainly because most cross-border transport contracts, especially carriage by air, are international in nature and international conventions exist as to the substantive rights

\footnotetext{
${ }^{38}$ Art 15(1) Brussels I Regualtion; art 6(1) Rome I Regulation.

${ }^{39}$ Case C-89/91, Shearson Lehmann Hutton v TVB Treuhandgesellschaft fur Vermogensverwaltung und Beteiligungen [1993] ECR I-139; Case C-269/95, Francesco Benincasa v Dentalkit Srl [1997] ECR I-3767; Case C-99/96, Hans-Hermann Mietz v Intership Yachting Sneek BV [1999] ECR I-2277; Case C-464/1, Gruber v Bay Wa AG [2005] ECR I-439.

${ }^{40}$ Standard Bank London v Apostolakis [2002] CLC 933. See discussion in Hess, B., Pfeiffer, T. and P. Schlosser, 'Report on the Application of Regulation Brussels I in the Member States', Study JLS/C4/2005/03.

${ }^{41}$ Art. 15(3) Brussels I Regulation; art. 6(4)(b) Rome I Regulation.
} 
and obligations, procedure and conflict of laws arising out of these contracts. ${ }^{42}$ It is believed that applying protective conflicts rules in transport contracts may conflict with the existing international conventions and cause difficulties. ${ }^{43}$ However, although transport contracts are excluded from consumer protection, they are nevertheless covered in the general European conflict of laws. Special jurisdiction in art. 5(1) of the Brussels I Regulation, for example, applies to carriage by air claims between businesses and consumers fallen outwith the Montreal Convention but falling under the EU Denied Boarding Directive, ${ }^{44}$ and art. 5 of the Rome I Regulation provides separate choice of law rules for carriage contracts. A large number of crossborder consumer contracts concluded online are transport contracts. Most transport operators and airlines have maintained websites and have reserved some competitive fares to website purchase only. It is disadvantageous to most e-consumers that protective private international law does not apply to transport contracts.

Besides, the Rome I Regulation also excludes from the scope of protection services contracts where services are provided exclusively in a country other than the consumer's habitual residence. ${ }^{45}$ As a result, if a consumer booked a hotel accommodation or a holiday in another country, the law of his habitual residence no longer protects the consumer. Instead, the law of the place where services are provided should systematically apply. This is mainly because requiring a hotel or a restaurant to comply with different customers' domestic laws is unrealistic. Given the international nature of hotel services, it is detrimental to require hotel operators to ring-fence the market to one particular country.

Although transport contracts are excluded from the scope of protection, package travel contracts where transport is one part are included. ${ }^{46}$ Package travel is defined as 'the pre-arranged combination of not fewer than two of the following when sold or offered for sale at an inclusive price and when the service covers a period of more than twenty-four hours or includes overnight accommodation: (a) transport; (b) accommodation; (c) other tourist services not ancillary to transport or accommodation and accounting for a significant proportion of the package'. ${ }^{47}$ The main reason to include package travel in the protective conflicts rules is because the consumer concludes a single transaction which combines different tour services. The exclusion of transport contracts and certain services contracts for choice of law would make each unit in the transaction subject to a different jurisdiction and choice of law rules, causing uncertainty and extra cost. ${ }^{48}$ Online package travel experiences 'high double

\footnotetext{
${ }^{42}$ E.g. Convention on the Contract for the International Carriage of Goods by Road of 1956; Convention for the Unification of Certain Rules for International Carriage by Air (Montreal Convention) of 1999.

${ }^{43}$ Art. 13, Jenard Report; Part 1, Schlosser Report.

${ }^{44}$ E.g. Case C-204/08 Rehder v Air Baltic [2009] ECR I-6073. The case concerns the application of the Regulation (EC) No 261/2004 Establishing Common Rules on Compensation and Assistance to Passengers in the Event of Denied Boarding and of Cancellation or Long Delay of Flights, and Repealing Regulation (EEC) No 295/91, [2004] OJ L46/1.

${ }^{45}$ Art. 6(4)(a). This type of contract, however, is still protected in terms of jurisdiction.

${ }^{46}$ Art. 15(3) Brussels I Regulation; art. 6(4)(b), Rome I Regulation; Joined Cases C-585/08 and C144/09 Pammer v Reederei Karl Schluter GmbH and Hotel Alpenhof GesmbH v Heller [2010] ECR I12527.

${ }^{47}$ Directive 90/314/EEC on package travel, package holidays and package tours, [1990] OJ L158/59, art. 2(1).

${ }^{48}$ Pocar, F. 'Explanatory report on the Lugano Convention 2007' ('Pocar Report 2007'), [2009] OJ C319/21, para 84.
} 
digit growth, fuelled by dynamic packaging ${ }^{49} \mathrm{E}$-commerce is particularly convenient for dynamic packaging, that is, consumers could build their own package by selecting flights, accommodation, car rental, airport parking, show tickets, and so on. It is, however, uncertain whether dynamic packaging is covered in the definition of package travel in the Brussels I and Rome I Regulations. While the consumer has selected and booked more than one travel service with one inclusive price, the consumer concludes contracts with individual service suppliers respectively instead of one single trader or operator. Dynamic packaging is superior to traditional defined packaging in terms of cost, flexibility, and personalisation and it is welcomed by consumers. According to the travel agent lastminute.com, online agents predict growth of 32 per cent coming from dynamic packaging. ${ }^{50}$ It is detrimental to consumers if they are deprived of the protection in dynamic packaging. The European Commission, thus, published a proposal in 2013, which clearly extends the definition of package travel to services which 'are put together by one trader, including at the request or according to the selection of the traveller, before a contract on all services is concluded'. ${ }^{51}$ A 'package' also exists when consumers conclude separate contracts with each service provider if the services are 'purchased from a single point of sale within the same booking process', 'offered or charged at an inclusive or total price', use the term 'package', 'combined after the conclusion of a contract by which a trader entitles the traveller to choose among a selection of different types of travel services', or 'purchased from separate traders through linked online booking processes where the traveller's name or particulars needs to conclude a booking transaction are transferred between the traders at the latest when the booking of the first service is confirmed'. ${ }^{52}$ The proposal has sufficiently taken special online transaction models into consideration and could benefit e-travellers.

The Rome I Regulation also excludes contracts relating to rights in rem in immovable property or tenancies from the scope of protection, except the right to use immovable property on a timeshare basis. ${ }^{53}$ It also does not cover rights and obligations constituting a financial instrument. ${ }^{54}$

\section{Defendant Domiciled or Deemed to be Domiciled in EU}

It is necessary to note that protective private international law in consumer contracts has territorial limits. As to choice of law, the Rome I Regulation applies to all contractual obligations not excluded from its scope, irrespective of the parties' habitual residence and whether the designated applicable law is the law of a nonMember State. ${ }^{55}$ EU jurisdiction rules within the Brussels I Regulation apply to disputes where the defendant has his domicile within one of the EU Member States. However, in consumer contracts, if a non-EU defendant has a branch, agency or other

\footnotetext{
49 Davies, P. (2006) 'Online travel makes further inroads into package arena', Travel Mole, 26 September, $\quad$ accessed $\quad 15 \quad$ April 2014 at, http://www.travelmole.com/news_feature.php?news_id=1111196\&c=setreg\&region=2.

${ }^{51}$ European Commission, 'Proposal for a Directive of the European Parliament and of the Council on package travel and assisted travel arrangements, amending Regulation (EC) No 2006/2004, Directive 2011/83/EU and repealing Council Directive 90/314/EEC, 2013/0246 (COD), COM(2013) 512 final, art. 3(2)(a).

${ }^{52}$ Art. 3(2)(b).

${ }^{53}$ Art. 6(4)(c) and Recital 27, Rome I Regulation.

${ }^{54}$ Art. 6(4)(d) and (e).

${ }^{55}$ Art. 2 Rome I Regulation.
} 
establishment in one of the Member States, the defendant is deemed to be domiciled within that state while a dispute arises out of the operation of the business establishment. ${ }^{56}$ This provision may bring many e-businesses domiciled in third countries within the scheme of the protective jurisdiction if the e-business has an 'establishment' within one of the Member States. It is uncertain as to what can be considered as an establishment within electronic commerce. ${ }^{57}$ The existing CJEU case law suggests that a business 'establishment' must have the following characteristics: it has a fixed permanent appearance, could conduct continuous instead of one-off commercial activities, is subject to the direction of the parent, could act in a way that binds the parent, and has certain degrees of autonomy. ${ }^{58}$ Thus an interactive website hosted in one of the Member States and accessible permanently in others, could facilitate the conclusion of contracts on behalf of parents, bind parents and therefore meet all the requirements and be classified as an establishment. ${ }^{59}$ If the concept is broad enough to include any e-agent or e-store that can be accessed in a Member State, it could theoretically bring all third country e-companies into the protective jurisdiction scheme. As a result, European private international law not only has community effects but also has impact on the international dimension. ${ }^{60}$

\section{Expectation of Businesses}

The fourth limitation is the most important one. For all contracts not expressly excluded from the Brussels I and Rome I Regulations, protective private international law applies where the businesses could reasonably expect to be subject to the jurisdiction and choice of law of the consumer's home. ${ }^{61}$ In other words, protective private international law does not apply blindly to all consumer contracts included in the protective scheme. It can only apply if the business has targeted or marketed in the consumer's home, which makes jurisdiction and applicable law of this country predictable. This requirement is designed to achieve commercial security. It is unreasonable to provide consumer unlimited protection even if it is the consumer who approaches the business in the latter's home to complete a transaction, though the latter has never intended to be subject to any foreign judicial systems.

Determining business expectations, however, is not easy, particularly in ecommerce. Different tests are proposed. The subjective approach proposes that the business must have a true intention to target the consumer's home. ${ }^{62}$ This suggestion is criticized for being unrealistic. On the one hand, it is hard to assess whether a business has 'true' intention especially when it conducts online trading; on the other hand, if a business has repeated transactions with consumers resident in a particular country, it is unfair to release the business from consumer protection rules simply

\footnotetext{
${ }^{56}$ Art. 15(2) Brussels I Regulation.

${ }^{57}$ Reed, C. (2001), 'Managing regulatory jurisdiction' 38 Houston Law Review 1003; Oren, J. (2001), 'Electronic agents and the notion of establishment' 9 International Journal of Law and Information Technology 249, s. 4.1.3; Tang, supra n. 5, pp. 66-73.

${ }^{58}$ Reed, C. (2004), Internet Law: Text and Materials 2nd edn., Cambridge: Cambridge University Press, p. 201, para. 10.81.

${ }^{59}$ Cf. ibid, p. 201; Fawcett, Harris, and Bridge, supra n. 5, para. 10.83.

${ }^{60}$ Economic and Social Committee Opinion, para. 4.2.2.

${ }^{61}$ The only exceptions are credit sale contracts. In terms of jurisdiction, all consumers are protected in credit sale contracts, irrespective of the business's expectation. Art. 15(1)(a) and (b) Brussels I Regulation.

${ }^{62}$ Foss and Bygrave, supra n. 32, 118; cf. Oren, supra, n. 57, 89.
} 
because the 'intention to target' cannot be proved. ${ }^{63}$ The objective approach is thus more realistic, that is, whether the online conduct of the business demonstrates that it has targeted a particular country as a matter of fact. The 'targeting' test is discussed in detail in the next section.

\section{IV. 'TARGETING’ CONSUMERS THROUGH THE INTERNET}

\section{A. From Accessibility to Interactivity}

Ever since the birth of the new arrangement in the Brussels I Regulation, the adoption of the expression of 'direct to' has been questioned and criticized. The European Economic and Social Committee, for example, stated its opinion that the expression 'is not clear enough to foster a climate of trust between the parties'. ${ }^{64}$ This was probably because the European Commission once had given a very generous interpretation to 'direct to'. Recital 13 of the Commission Proposal 1999 states that 'whereas, in particular, electronic commerce in goods or services by a means accessible in another Member State constitutes an activity directed to that State'. ${ }^{65}$ The accessibility approach has also been adopted, at least partially, in domestic courts of some Member States. For example, a German court held that a business had directed its business at Germany by holding a website in German language accessible in Germany. ${ }^{66}$

The accessibility approach has been criticized by most Internet lawyers and has been abandoned by the Commission. In 2000, the European Parliament proposed that: ${ }^{67}$

'The concept of activities pursued or directed towards a Member State is designed to make clear that point (3) [Article 15.1(c)] applies to consumer contracts concluded via an interactive website accessible in the State of the consumer's domicile. The fact that a consumer simply had knowledge of a service or possibility of buying goods via a passive website accessible in his country of domicile will not trigger the protective jurisdiction.'

This interpretation first of all rejected the pure 'accessibility' approach and proposed a new 'activity' test. This test suggests that only if an 'interactive' website is accessible in the consumer's home and a contract is entered into via the website, has the business targeted the consumer's home. A purely 'passive' website does not trigger the potential protective jurisdiction. This approach is similar to the contribution made in the USA. In the US case Zippo Manufacturing Co $v$ Zippo Dot Com ${ }^{68}$ the US District Court for the Western District of Pennsylvania ruled that in order to establish jurisdiction over a website the court should consider the activity of the website. If the website is active, which includes 'knowing and repeated transmission of computer files', taking jurisdiction is proper; if the website is passive, 'where a defendant has simply posted information on an Internet website which is accessible to users in

\footnotetext{
${ }^{63}$ Oren, supra n. 57, 89.

${ }^{64}$ Economic and Social Committee Opinion, para 4.2.4.

${ }^{65}$ Commission Proposal, recital 13. It shows that the Commission does not make a clear clarification between 'accessibility' and 'activity' of a website.

${ }^{66}$ Hess, Pfeiffer, Schlosser, supra n. 40, 1450146; VznGr Den Haag, NIPR 2005, 168.

${ }^{67}$ European Parliament, 'Proposal for a Council Regulation (EC) on Jurisdiction and the Recognition and Enforcement of Judgments in Civil and Commercial Matters (Presented by the Commission)', COM (1999) 348 final 99/0154 (CNS).

68952 F.Supp. 1119 (W.D.Pa. 1997).
} 
foreign jurisdictions', taking jurisdiction is improper; if the website is in the middle, that is, the interactive website, 'where a user can exchange information with the host computer', taking jurisdiction depends on 'the level of interactivity and commercial nature of the exchange of information that occurs on the website' ${ }^{69}$ There is a fundamental difference between the Zippo case and the protective jurisdiction in the Brussels I Regulation. The Zippo case concerns jurisdiction in trade mark infringement and tort cases, not contracts or consumer protection cases. ${ }^{70}$ However, there is also similarity that allows European law-makers to consider the effect of the sliding-scale test. The Zippo case provides a test to determine whether the defendant has 'purposefully availed' himself of the jurisdiction of a country. Where a defendant purposefully avails himself of the control of a country at distance through the Internet, the defendant generally is required to 'target' that country. This 'target' may not be subjective, but objective, reflected by activities, for example, how frequent the ebusiness has transactions with the residents of the particular country and how easily and effectively the e-business enables and solicits the consumers of this country to enter into transactions. Article 15(1)(c), on the other hand, aims to provide certainty to businesses and will only subject them to the consumer's domicile if they have willingly targeted that country. Although the US and EU jurisdiction rules are formed on different philosophy and legal bases, they share similarity in terms of looking for a basis to subject a distant company to jurisdiction. Both aim to protect the defendant from unfair surprises and both require activities to show that the defendant could reasonably expect to be subject to the jurisdiction of a country.

The European Parliament's proposal clearly follows the same line as the US approach, by separating commercial websites into 'interactive' and 'passive'. ${ }^{71}$ It is necessary to note that the terminology in the Parliament proposal is slightly different from that of the USA. In Zippo, websites are classified into 'active', 'interactive' and 'passive'. In the Parliament's proposal, websites are classified into 'interactive' and 'passive'. The 'interactive' website in the proposal refers to a website which could exchange information with consumers and facilitate the conclusion of contracts and, sometimes, their performance. ${ }^{72}$ According to the Parliament, an interactive website satisfies the 'targeting' test while a passive website does not.

Many commentators have criticized the Zippo decision by pointing out the difficulty of classifying websites into different categories. It is true that drawing a clear line between active, interactive and passive websites is tough. ${ }^{73}$ Furthermore, it is even tougher to further classify 'interactive' websites into pro-active and propassive sites. ${ }^{74}$ The Parliament seems to have simplified the task by classifying websites into two larger categories. However, it does not truly bring certainty to practice. It is still uncertain where exactly the line should be drawn. The passive website can be defined very narrowly where it does no more than advertise products and services, only offering consumers knowledge of the products sold and services

\footnotetext{
69952 F.Supp. 1119, 1124.

${ }^{70}$ Hill, supra n. 5, pp. 137-8; Tang, supra n. 5, pp. 113-14.

${ }^{71}$ Parliament proposal.

${ }^{72}$ For example, the website incorporated an online payment system, which allows the consumer to pay online by using a credit card, or a website allows the download of software or other digital products after receiving payment from consumers.

${ }^{73}$ Winfield Collection v Mc Cauley 105 F Supp 2d 746, 750 (ED Mich 2000); Tang, supra n. 5, pp. 11213; M. Geist (2001), 'Is there a there there? Towards greater certainty for internet jurisdiction' 16 Berkeley Technology Law Journal 1345, 1354; Berman, P. (2002), 'The globalisation of jurisdiction' 151 University of Pennsylvania Law Review 311, 410.

${ }^{74}$ Tang, supra n. 5, p. 113.
} 
provided. A passive website may also provide consumer contact information for the business or provide information on how to place an order. This website may still be passive in that there is no direct exchange of communication between the consumer and the business via the website. This site, however, may still be directed to the consumer's domicile, and if the consumer does enter into contract with the company at distance by following the information provided online, it is hard to argue that the business does not direct its commercial activities to the consumer's home. However, it is arguable that the protective jurisdiction is not triggered by the website, but by the later activities of the business in receiving the consumer's order placed at distance.

In any case, the distinction between 'interactive' and 'passive' websites is not an appropriate approach in that the activity of the website does not necessarily imply the purpose and expectation of the business. A business may establish an interactive website which is accessible in all Member States but is only intended to conduct domestic transactions. ${ }^{75} \mathrm{~A}$ business may not be able to properly control the accessibility of a passive website as well as an interactive website. The question is whether a business is obliged to take positive steps to prevent a contract from being concluded with consumers domiciled in a market that the business does not want to target. The answer is positive. A business is not allowed to enjoy the benefit received from a contract and to escape protective jurisdiction by claiming it could not control the website well. A number of instruments can be adopted to prevent unwanted contracts, including making a clear declaration online, rejecting delivery to countries out of its targeted markets, or blocking access or placing of orders by consumers located in certain countries by testing the IP address. ${ }^{76}$ It is arguable that technology was not well developed a decade ago, which made efficient ring-fencing difficult. However, ring-fencing is generally effective now. Many multinational companies invite consumers to select their habitual residence/domicile and then bring the consumers to the website designed particularly for their country. Some small and medium-sized companies do not have sufficient financial power to maintain more than one website targeting different countries. They will usually include a declaration in their website, requiring consumers to provide information about their delivery address, and refuse delivery to unwanted markets.

These methods combined, are in most cases effective in protecting the reasonable expectations of business. In other words, the Internet is no longer completely out of control. The majority of consumer-oriented e-selling relates to physical delivery of goods. A business could certainly control the destination of delivery. The only problem is the possibility of the delivery address differing from the consumer's home address. Article 15(1)(c) does not include a provision to include or exclude mobile consumers from its scope. In other words, if the website is directed to the consumer's home and the contract is within the framework of the website, the business is subject to the consumer's home jurisdiction, regardless of where the contract is concluded.

\section{B. Comprehensive Approach}

\footnotetext{
${ }^{75}$ See Hess, Pfeiffer, Schlosser, supra n. 40, 146.

${ }^{76}$ Oren, supra, n. 57, 69; Foss and Bygrave, supra, n. 32, n. 74.
} 
Realising the uncertainty and concerns about Article 15(1)(c) of the Brussels I Regulation, the Council and the Commission have published a joint statement which says that: ${ }^{77}$

'...for Article 15(1)(c) to be applicable it is not sufficient for an undertaking to target its activities at the Member State of the consumer's residence, or at a number of Member States including that Member State; a contract must also be concluded within the framework of its activities. This provision relates to a number of marketing methods, including contracts concluded at a distance through the Internet.

In this context, the Council and the Commission stress that the mere fact that an Internet site is accessible is not sufficient for Article 15 to be applicable, although a factor will be that this Internet site solicits the conclusion of distance contracts and that a contract has actually been concluded at a distance, by whatever means. In this respect, the language or currency which a website uses does not constitute a relevant factor.'

The statement shows at least five points. First, the pure accessibility test is abandoned. E-businesses should not worry that simply by maintaining a website they will automatically be subject to the jurisdiction and applicable law of other Member States. Second, the website must solicit distant consumers to enter into the contract. How can it be decided if a website has solicited consumers into transactions? For a website to 'solicit' a consumer into a contract, some conditions must be fulfilled. First of all, the consumer must know the existence of the website and must have viewed the website before entering into the contract. ${ }^{78}$ If a consumer did not know a website existed or did not browse the website but has acquired information about the products offline, even if the business has a website, the consumer was not solicited into the contract by the website. In Re the Website of a Czech Discotheque ${ }^{79}$ for example, an Austrian consumer entered into a contract without knowing of the existence of the defendant's website accessible in Austria. The consumer was clearly not solicited into the contract by the website. Furthermore, the browsing of the website must be the reason why the consumer entered into a contract, or travelled abroad to enter into a contract. To decide whether the website is a reason that the consumer enters into a contract, a variety of facts should be taken into account. The Council and the Commission say in the Joint Statement that the country-specific indicia are not relevant factors to make the protective jurisdiction rules apply. ${ }^{80}$ It is suggested that the real meaning is that country-specific indicia should not be the 'sole' factors in deciding whether a website has targeted another country. ${ }^{81}$ These indicia, such as the language and currency, nevertheless, are certainly relevant factors that a court could take into account to decide whether a website did solicit consumers into transactions. If a consumer could not understand the language, for example, it is a strong reason to demonstrate that the website does not solicit the consumer into the contract. In Re the Website of a Czech Discotheque, ${ }^{82}$ the website in dispute used Czech which is not understood by the

\footnotetext{
77 The Council and the Commission, 'Joint Statement on Articles 15 and 73' ('joint statement') accessed 15 April 2014 at http://ec.europa.eu/civiljustice/homepage/homepage_ec_en_declaration.pdf.

${ }^{78}$ Re the Website of a Czech Discotheque, Case 2 Ob 256/08y, [2010] I.L.Pr. 5.

${ }^{79}$ Case 2 Ob 256/08y, [2010] I.L.Pr. 5.

${ }^{80}$ Joint Statement, supra n. 77, n. 55. the language or currency which a website uses does not constitute a relevant factor.

${ }^{81}$ See Pammer v Reederei Karl Schluter GmbH and Hotel Alpenhof GesmbH v Heller, paras 92-94.

${ }^{82}$ Case 2 Ob 256/08y, [2010] I.L.Pr. 5.
} 
majority of Austrian residents. This factor was accepted by the Austrian court to show that the website did not target Austrian consumers. In Pammer v Reederei Karl Schluter GmbH and Hotel Alpenhof GesmbH v Heller, the CJEU suggests that the following matters are relevant, including the international nature of business activities, mention of consumers from other Member States going to the trader's place, use of language or currency, possibility of making and confirming reservations or order in a foreign language, mention of a telephone number with an international code, outlay of expenditure on an Internet referencing service, use of a top-level domain, and display of an international clientele composed of consumers domiciled in other Member States. ${ }^{83}$

Third, it does not matter whether the e-business has 'subjectively' targeted the consumer's domicile. ${ }^{84}$ As far as a website has, as a matter of fact, facilitated the sale, the business is subject to the protective jurisdiction and choice of law rule. The language and currency, for example, sometimes could show that the e-business has the intention of marketing in a particular country. If the country-specific indicia are very special, they may have stronger weight when being used in a positive manner, to show a business 'wants' to target a country. They would be given less weight if one wants to rely on them to prove a business 'does not' want to target a country. For example, a website uses pounds as an acceptable currency to pay for the purchases. This is a strong indication that the e-company wishes to target the UK. However, the Joint Statement now shows that this factor is no longer important. One should not consider what a business wishes to do, but consider what the real life effect of a website is. No matter what language and currency are used, only if the consumer was attracted into the transactions could the protective conflicts rules apply. For the same reason, if the business states in the website that it 'does not wish' to target particular countries, while the real practice does not correspond with the statement, or at least no positive act has been done to prevent unwanted transactions, it still has objectively 'solicited' consumers into contracts. ${ }^{85}$ It, however, needs to be noted that the Joint Statement is only a recommendation and has no binding effect. ${ }^{86}$ The CJEU in Pammer and Hotel Alpenhof continued to consider whether the business is 'envisaging doing business with consumers domiciled in one or more Member States' ${ }^{87}$ Certainly, if there is sufficient evidence to prove such intention, there is no reason to subject business to the protective rules. The question is whether proving intention is necessary. The Joint Statement seems to have simplified the burden of proof.

Fourth, the concept of 'soliciting' does not concern the nature of a website, that is, whether it is active or passive. ${ }^{88}$ The real effect of a website does not depend on whether it is active or not. If a website is completely passive, that is, it provides advertisements only, it could still solicit a consumer into a contract. The only difficulty is that the contract cannot easily be concluded online. This, however, does not matter if a contract is eventually concluded within the framework of the website. On the other hand, whether a website is interactive or active, it cannot subject an e-

\footnotetext{
${ }^{83}$ Paras 92-94.

${ }^{84}$ Bogdan, M. (2012), 'Defamation on the internet, forum delicti and the E-Commerce Directive', in Bonomi, A. and G. Romano, Yearbook of Private International Law 2012, Munich: Sellier European Law p. 486.

${ }^{85}$ Hess, Pfeiffer, Schlosser, supra n. 40, 147, citing German case, 03/30/2006, JZ 2006, 1187.

${ }^{86}$ Bogdan, M. (2011), 'Website accessibility as basis for jurisdiction under the Brussels I Regulation' 5 Masaryk University Journal of Law and Technology 1, 7.

${ }^{87}$ Para. 76.

${ }^{88}$ Hess, Pfeiffer, Schlosser, supra n. 40, 146.
} 
business to protective conflicts law if the website does not have a real effect on the consumer's decision to buy. ${ }^{89}$

Fifth, it does not matter whether the contract was entered into online, through the website, or offline. If a contract is concluded within the framework of the activities, the targeting test is fulfilled.

The comprehensive approach requires one to consider not the nature of a website, or the subjective intention of the business, but the effect of the website, that is, whether it has solicited a consumer into a contract within the framework of the activities. Compared to previous approaches proposed either by legislators or by academic writers, the comprehensive approach has three advantages. It is flexible in that it does not impose rigid rules and test standards that must be blindly applied to each individual case. Flexibility is particularly important in e-commerce, because each website presents different characteristics and consumers enter into contracts under different circumstances. Rigid rules designed for pre-designated circumstances would inevitably lead to unfairness in cases that include unexpected situations. Second, it does not distinguish websites as interactive or passive, nor distinguish consumers as mobile or static. ${ }^{90}$ As far as consumers are solicited into transactions, even if consumers do not take all necessary steps within their domicile, or the website is passive only, consumers are still eligible for protection. It avoids difficult classification issues in e-commerce. Third, it applies to all types of transactions involving the use of a website. It applies not only to Internet trading via the website maintained and controlled directly by the e-business, but also via the use of a thirdparty platform, such as eBay or Amazon. ${ }^{91}$ It is thus improper to rely on the characteristics of the website to determine whether the e-business concerned has targeted the consumer's domicile, as all e-businesses will use the same platform to sell. E-businesses will only be able to ring-fence their market by two means: one is to provide a clear statement that it will only trade with consumers in particular countries; another is to control its market at the delivery stage. If the company does not 'ringfence' and the consumer enters into the contract, protective conflicts rules should apply because the consumer is solicited into the contract by the Internet site.

\section{PARTY AUTONOMY IN E-CONSUMER CONTRACTS}

Having said that the effect of party autonomy is limited in e-consumer contracts under European private international law, however, is not to say that it is completely excluded. In terms of jurisdiction, the parties in a consumer contract are still allowed to choose the competent court if they have made the choice after disputes have arisen, if the choice has expanded instead of limited the consumer's option, and if they have chosen their common domiciles at the time of contracting. ${ }^{92}$ In terms of choice of law, the parties are allowed to choose the governing law which will provide the higher standard of protection provided by mandatory rules of the consumer's habitual residence. ${ }^{93}$ Furthermore, there are some special contracts which are consumer

\footnotetext{
${ }^{89}$ The nature of websites is irrelevant in Pammer and Hotel Alpenhof.

${ }^{90}$ Previous conditions in art. 13 of the Brussels Convention and art. 5 of the Rome Convention distinguish consumer into mobile and static and do not protect mobile consumers.

${ }^{91}$ eBay, www.ebay.com; Amazon, www.amazon.com. They are two famous multinational e-commerce companies providing virtual marketplace, online auctions and shopping opportunities for consumers and small e-sellers.

${ }^{92}$ Art. 17 Brussels I Regulation.

${ }^{93}$ Art. 6(2) Rome I Regulation: 'Notwithstanding paragraph 1, the parties may choose the law applicable to a contract which fulfils the requirements of paragraph 1, in accordance with Article 3.
} 
contracts in nature, but which are excluded from the scope of protection for other reasons. ${ }^{94}$ Party autonomy is fully applicable in these contracts.

Although the doctrine of party autonomy is generally intact from the challenge of e-commerce, the Internet has imposed practical and technical problems which need to the clarified. Jurisdiction or choice of law agreements in e-consumer contracts are usually concluded in the form of click-wrap contracts. During the process of concluding the contract, the terms and conditions will be displayed and consumers are required to click 'I agree' or 'I accept' in order to submit the order. Are these clickwrap agreements valid under European private international law?

A uniform choice of law rule is provided to decide formal validity of a choice of law agreement in consumer contracts, which will be the law of the consumer's habitual residence. ${ }^{95}$ This section will only consider formal validity requirements in the Brussels I Regulation. Article 23(1) of the Brussels I Regulation says that a jurisdiction agreement is formally valid if it is concluded in writing or evidenced in writing, if it complies with the common practice between the parties and if it complies with the usage and customs in the trade. In e-consumer contracts, the first challenge might be whether a jurisdiction agreement is concluded 'in writing'. Article 23(2) clarifies that 'in writing' includes '(a)ny communication by electronic means which provides a durable record of the agreement'. A click-wrap agreement, as far as it can be recorded in a durable form, is intact in art. 23. Furthermore, the European Commission has specifically confirmed that the formal requirement does not intend to 'invalidate a choice-of-forum clause concluded in a form that is not written on paper but accessible on screen' ${ }^{96}$ However, what if the consumer claims that he did not have a chance to read or he did not notice the existence of the jurisdiction agreement in the terms and conditions? The CJEU has, in past case law, demonstrated the policy of requiring the jurisdiction clause to be written in a manner that could provide sufficient notice to the other party. ${ }^{97}$ A term printed on the reverse side of a contract without any reference on the face was held invalid. ${ }^{98}$ As a result, in e-commerce, if the consumer is not well directed to the jurisdiction agreement, even if the consumer has clicked to accept, this agreement is invalid as to form. This could be the case if the jurisdiction clause is included in the terms and conditions, which are not displayed on the webpage, the link to which is not provided, or there is no reference directing consumers' attention to the terms and conditions. It is uncertain whether a website must be able to 'force' consumers to read through before they could conclude click wrap contracts. For example, some websites are equipped with software that displays part of the terms and conditions within a box with a rolling bar. The click-button 'I accept' is inactivated. Only after the user draws the bar to the bottom which shows that the user has read through the terms, is the 'I accept' link activated and the consumer can proceed to the next stage to conclude the contract. Some websites adopt a fixed time system. The 'I accept' button is inactivated until the terms and conditions

Such a choice may not, however, have the result of depriving the consumer of the protection afforded to him by provisions that cannot be derogated from by agreement by virtue of the law which, in the absence of choice, would have been applicable on the basis of paragraph 1.'

${ }^{94}$ Such as transport contracts (art. 15(3) Brussels I Regulation; art. 6(4)(b) Rome I Regulation), some services contracts (art. 6(4)(a) Rome I Regulation), and contracts on financial instruments (art. 6(4)(c) and (d) Rome I Regulation).

95 Art. 11(4) Rome I Regulation.

${ }^{96}$ Commission Proposal 1999, Art 23.

${ }^{97}$ Case 24/76 Estasis Salotti di Colzani Aimo e Gianmario Colzani v RUWA Polstereimaschinen GmbH [1976] ECR 1831.

98 Ibid. 
are displayed for 60 seconds on the webpage. Both are all that e-businesses could do to maximise the chances of consumers to read the terms and conditions and to provide real consent. These devices certainly will make the jurisdiction agreement valid. However, they are not mandatory. Even if these instruments are used, the majority of consumers still do not read through these terms. As far as the jurisdiction clause is clearly displayed and consumers are adequately noticed of its existence, the clause should be held valid as to form. ${ }^{99}$

It is a common practice for an e-business to establish a website that requires consumers to register. When the consumer first uses the website to buy, he is required to go through the full process, by providing his name and address and by being required to read and accept the terms and conditions, which normally include a jurisdiction agreement. If the consumer purchases from the website for the second time, he is a returning consumer and can conclude contracts fairly quickly, by simply signing in. He is no longer required to read and agree upon the terms and conditions. The question is whether the jurisdiction agreement concluded in the first transaction still binds the consumer. This raises two questions. First, is the jurisdiction agreement concluded in the previous transaction validly incorporated into the current transactions? It depends on what has been agreed between the parties. If the terms and conditions displayed at the time of registration clearly provide that they should apply to all subsequent transactions and consumers are fully notified, they may be incorporated in the current sale. If no such agreements exist and there is no notice in current transactions to refer to the general terms concluded before, they are not incorporated in the current contract. Second, if the jurisdiction agreement is not incorporated into the current contract, would it constitute 'common practice' between the parties? It is true that the same companies have entered into more than one agreement on usually similar transactions; however, using common practice in consumer contracts is inappropriate, because the common practice principle is based on implied consent between sophisticated business parties. They are experienced and qualified to project commercial risks and bound by their common practice. This principle clearly cannot work properly for consumer contracts to the disadvantage of consumers.

\section{ADR, ODR AND COLLECTIVE REDRESS}

Although protective jurisdiction and choice of law rules have generated several debates, it has been recognized by more and more researchers and practitioners that these rules are not used frequently in practice. ${ }^{100}$ The main reason is that consumer contracts are usually low-value contracts which make litigation, especially crossborder litigation, irrational. The small value nature is even so in e-commerce. Without the opportunity to investigate the product in advance, a consumer would usually not enter into large value contracts online. It appears that the protective jurisdiction and choice of law rules have much weaker real life impact than expected and they cannot really improve consumers' access to justice or encourage consumers to buy online.

\footnotetext{
${ }^{99}$ Anyway, even if technical devices are adopted, they cannot guarantee that consumers definitely read it. In practice, most consumers will simply drag down the bar and proceed to buy, or wait for the 'submit' button to be activated without actually reading or agreeing on the jurisdiction agreement.

${ }^{100}$ Schlosser states that '(a)bundant literature exists which is out of proportion to the practical impact of Section 4'. See Hess, Pfeiffer, Schlosser, supra n. 40, 144.
} 
In order to overcome the weakness in consumer litigation, the European Commission is also working to develop a multiple dispute resolution scheme for cross-border consumer disputes. Protective private international law continues to play an important part in the multi-dispute resolution scheme, including ADR, ODR and collective redress. If a consumer agrees to resolve disputes out of court, either by traditional ADR or ODR, the protective jurisdiction rule is no longer relevant because the ADR or ODR entity is only competent to attend a dispute when both parties agree to submit to it. If a consumer does not wish to submit to a foreign ADR entity, the business will not unilaterally generate the procedure. There is no need to protect consumers in terms of jurisdiction. Furthermore, the ADR Directive also provides that 'with regard to disputes arising from cross-border sales or service contracts, consumers can obtain assistance to access the ADR entity operating in another Member State which is competent to deal with their cross-border dispute'. ${ }^{101}$ This further reduces the jurisdiction difficulty. Finally, jurisdiction problems will be extinguished if ODR is used, which enables the parties to resolve their disputes online. The Regulation on ODR requires Member States to establish an ODR platform, which is 'an interactive website which can be accessed electronically and free of charge in all the official languages of the institutions of the Union'. ${ }^{102}$ The dispute will be processed and resolved online and neither party is required to be physically present in another country. Jurisdiction concerns will not arise at all in ODR. Protective choice of law, on the other hand, is still relevant. Pursuant to the ADR Directive, the solution imposed by the ADR entity should not deprive consumers of protection afforded by the mandatory rules of the consumer's habitual residence if the dispute falls within the scope of art. 6(1) and 6(2) of the Rome I Regulation. ${ }^{103}$ The same standard applies to ODR. ${ }^{104}$ This is particularly important especially where an ADR or ODR solution is going to be binding on both parties. Consumers will only be confident in cooperating if there are rules to guarantee that they will receive at least no substantively lower protection in ADR or ODR.

It is also necessary to note that out-of-court dispute resolution, especially ODR, may not be able to resolve all consumer disputes. For example, the very nature of ODR determines that it may not be able to resolve complicated disputes. Furthermore, effective and low-cost judicial redress should always be there to assist consumers. As a result, the European Commission has published a Recommendation to encourage Member States to adopt collective redress mechanisms to enable multiple consumers to combine their disputes against one defendant in one action. The Recommendation proposes that the national mechanism should be an opt-in scheme ${ }^{105}$ and a representative collective action can only be led by a qualified entity. ${ }^{106}$ However, a Member State cannot refuse to hear a cross-border collective redress based on the standing and admissibility of the claimant group or the representative entity domiciled

\footnotetext{
${ }^{101}$ Directive 2013/11/EU on Alternative Dispute Resolution for Consumer Disputes and Amending Regulation (EC) No 2006/2004 and Directive 2009/22/EC, [2013] OJ L165/63, art. 14(1).

102 Regulation (EU) No 524/2013 on online dispute resolution for consumer disputes and amending Regulation (EC) No 2006/2004 and Directive 2009/22/EC, art. 5(2).

103 ADR Directive, art. 11(1)(b) and (c), and recital 44.

${ }^{104}$ Regulation on ODR, art. 2.

105 The judgment will not bind particular consumers unless they expressly choose to opt-in. An opposite scheme is called 'opt-out', where a collective action judgment will bind all potential consumers unless they choose to opt-out. See the Recommendation, section V.

106 Arts 4-7.
} 
in another Member State. ${ }^{107}$ It suggests that the Commission Regulation allows panEuropean collective action in principle.

Collective redress could be useful in protecting consumers and businesses in e-commerce. One the one hand, while a business trades online, it usually establishes one website with a few mirror sites targeting consumers in different markets of its choice. Similar commercial practice in mass markets will lead to similar claims from more than one consumer. Resolving the similar claims separately, either in court or in ADR/ODR, is not considered economic. The best way is to enable these similar claims to be resolved together in one procedure. This redress method could reduce litigation costs to each consumer, and could also help businesses to resolve all complaints in one ruling instead of being subjected to multiple claims in the future.

The European Commission has also stated that the existing jurisdiction and choice of law rules should apply to collective redress. This raises questions as to how the current European private international law could fit into the special nature of collective redress. First, the protective jurisdiction could not be used in consumer representative action, because the action is brought by the representative entity against the business instead of by each individual consumer against the defendant. General jurisdiction rules in art. 5(1), as a result, will apply. Article 5(1) says that jurisdiction in relation to a contract should be the place where the goods are delivered or services provided. In e-commerce, where goods, such as digital products, are delivered online, or services are provided online, it is questionable as to where the Member State where goods are delivered or services provided is. ${ }^{108}$ The possible suggestions include the place of uploading, the place of the seller's server where the products are hosted, and the place of downloading. ${ }^{109}$ Until now, there is no clear answer to this question. In collective actions where digital products are downloaded by consumers domiciled in more than one Member State, the first option, that is, the place where goods are uploaded, may be more realistic. It points to one single jurisdiction in all consumer contracts. If the third option is adopted it could lead to multiple competent jurisdictions and may lead to the split of collective redress. ${ }^{110}$ The second option points to the country that may have factitious connections with both the disputes and the parties and should be abandoned.

Second, applying the protective choice of law rules in collective redress may lead to the position where consumers with their habitual residence in different Member States are entitled to the protection of mandatory rules of different Member States. It will lead to the application of different substantive law to different groups of consumers in one collective action, which is fundamentally inconsistent with the purpose of collective action, which is to facilitate convenient resolution of disputes with similar rights and obligations. Different substantive law imposes different rights and obligations which may prevent collective actions from being effectively brought in the circumstances. The current European jurisdiction and choice of law rules need reform in order to be compatible with future development of collective redress.

\section{CONCLUSION}

\footnotetext{
${ }^{107}$ Arts 17-18.

${ }^{108}$ Fawcett, Harris and Bridge, supra n. 5, paras 3.177-199.

${ }^{109}$ Fawcett, Harris and Bridge, supra n. 5, paras 10.60-75, and 10.105.

${ }^{110}$ For more discussion, see Tang, Z.S. (2011), 'Consumer collective redress in European private international law', 7 Journal of Private International Law $101 \mathrm{ff}$.
} 
It is concluded that although the Internet has brought challenges to the European jurisdiction and choice of law rules in consumer contracts, the challenges are not fundamental. The Internet challenge has been considered seriously by the legislators and guidance has been provided to help courts in the Member States in their practice. The current European conflict of laws generally works effectively in e-consumer contracts. At the least, no consumers or businesses have claimed that they are prevented from entering into e-commerce because of the worry about where to sue or be sued or which substantive law applies. However, in order to fully improve consumers' access to justice and to facilitate e-commerce, alternative dispute resolution methods and collective action should be adopted and developed. European private international law in consumer contracts should be reformed to accommodate the future development of these new redress methods. 